\title{
Research Paper \\ The Effect of Improving Business Environment on Economic Growth in Developing Countries
}

\author{
*Hedayat Hosseinzadeh ${ }^{1}$ (i) \\ 1. Assistant Professor, Department of Economics, Payame Noor University, Tabriz, Iran.
}

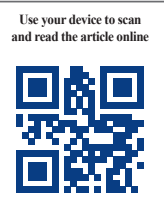

Citation Hosseinzadeh, H. (2018). The Effect of Improving Business Environment on Economic Growth in Developing Countries. Quarterly Journal of the Macro and Strategic Policies, 6(3), 498-517. http://dx.doi.org/10.32598/JMSP.6.3.498

dol' : http://dx.doi.org/10.32598/JMSP.6.3.498

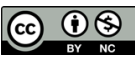

Funding: See Page 514

Received: 07 Oct 2017

Accepted: 04 Apr 2018

Available Online: 23 Sep 2018

Key words:

Economic growth, Growth models, Business environment, Generalized method of moments

\section{A B STRACT}

Business environment is one of the important factors affecting the economic growth and development. This issue depends on some other factors, and affects various contexts. Given the importance of the issue, regulatory authorities of countries and international organizations always evaluate its effects and propose operational guidelines to improve it. Because of the significance of the business environment index, this article investigate the effects of business environment on economic growth of 12 chosen countries of MENA Zone, using Generalized Method of Moments (GMM), from 2005 to 2013. The results indicate that business environment variables have positive and significant effects on economic growth. The only variable, which has negative and significant effect on economic growth, is regulations. This shows that cumbersome regulations cause a decrease in economic growth.

* Corresponding Author:

Hedayat Hosseinzadeh, PhD.

Address: Department of Economics, Payame Noor University, Tabriz, Iran.

Tel: +98 (914) 7690084

E-mail: hedhus@gmail.com 


\title{
اثر بهبود فضاى كسبوكار بر رشد اقتصادى در كشورهاى در حال توسعه
}

(1) 'هدايت حسينزاده"

\author{
1. استاديار، كروه اقتصاد، دانشُكاه بيام نور، تبريز، ايران.
}

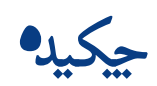

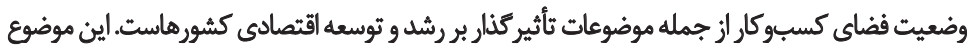

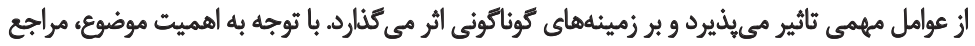

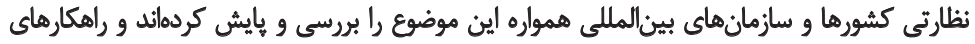

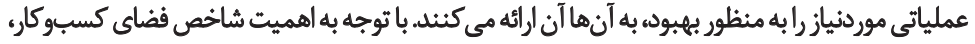

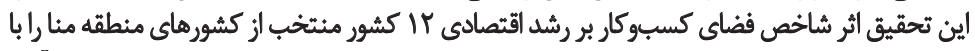

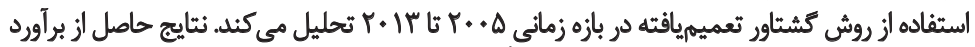

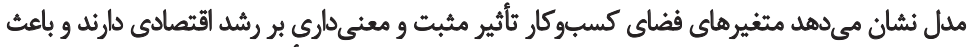

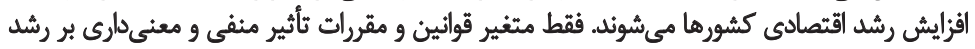

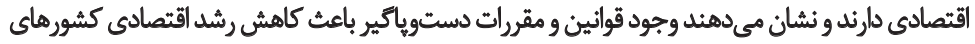

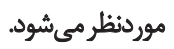

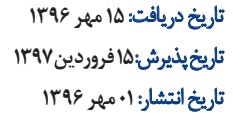

\section{: Lothlg}

رشد اقتصاديء مدل هاي ريد، فضاي كسبوكار، كشتئاور تعميميأقيته 


\section{dalo}

رشد و توسعه اقتصادى از مهممترين اهداف جوامع بشرى است. لازمه دستيابى به اين هدف، ايجاد و گسترش

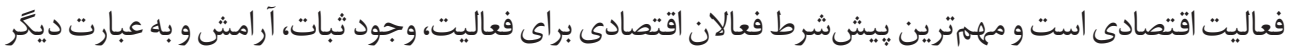

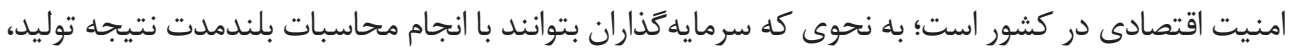

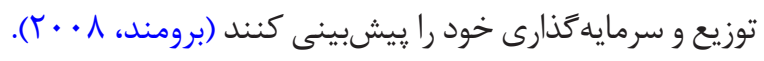

براى افزايش رشد و توسعه اقتصادى بايد شرايط موردنياز براى اين موضوع تحقق يابد. مىتوان شرايط محيطى

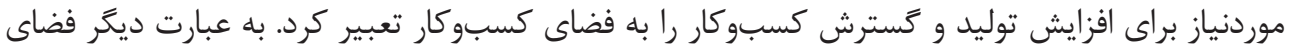

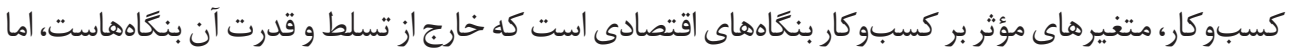

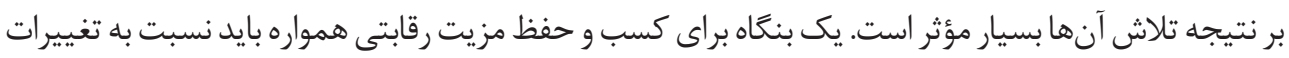

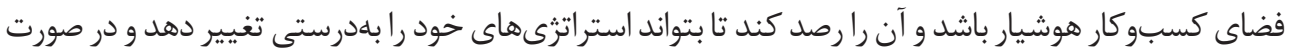

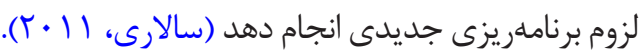
منظور از فضاى كسبو كار، عوامل مكثر بر عملكرد واحدهاى اقتصادى، مانند كيفيت دستخاههاى حاكميت،

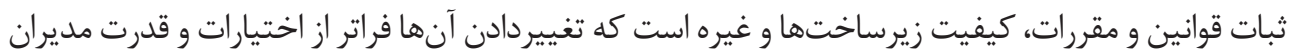

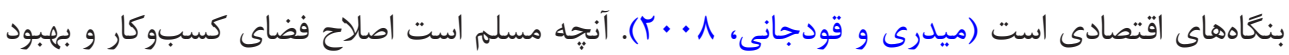

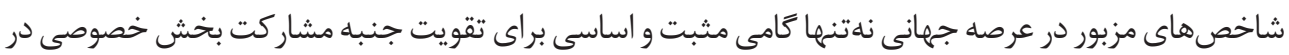

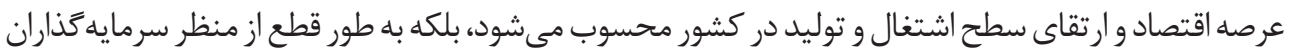

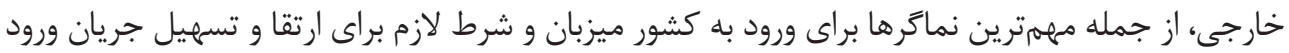

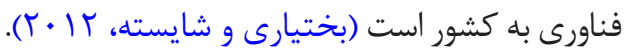

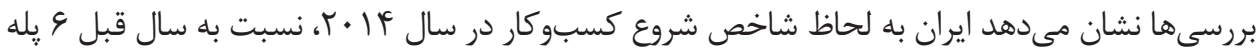

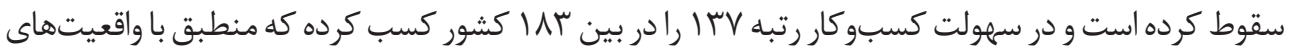

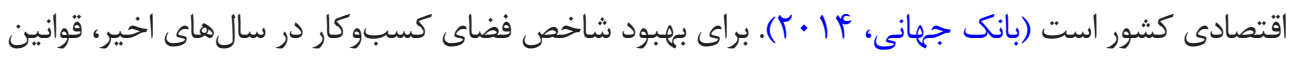

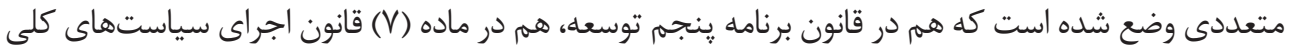

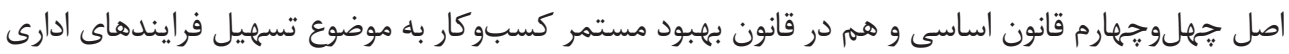

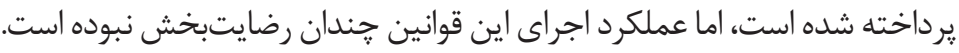

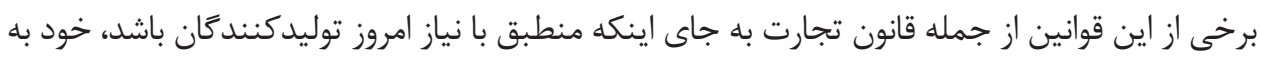

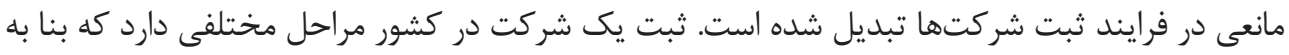

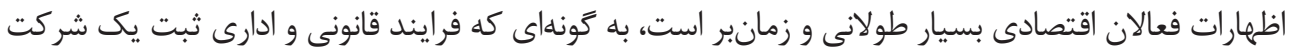

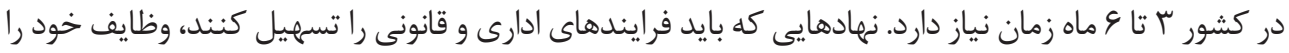

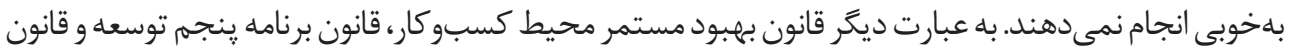

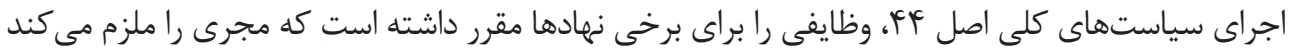




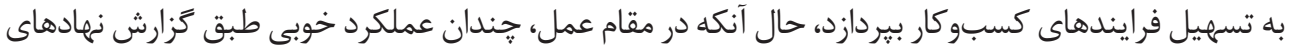

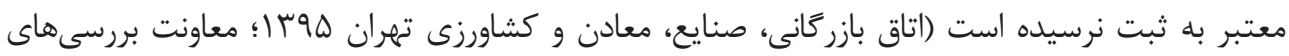

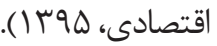

كشورهاى موفق در حوزه اقتصاد، در سالهاى اخير توانستهاند با بهبود شاخصهاى كسبو كار در جذب

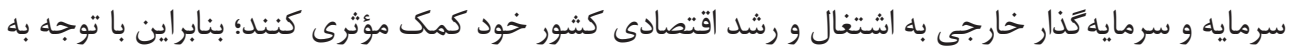

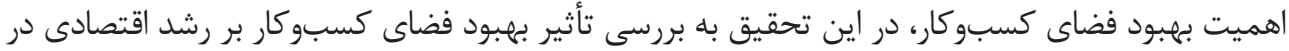

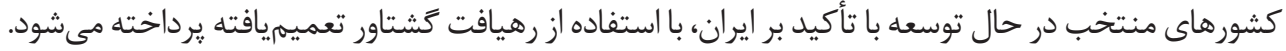

\section{1- ادبيات موضوع}

در اين بخش شاخصهاى فضاى كسبو كار و تأثير آن بر رشد اقتصادى بررسى مىشود.

\section{1- ( - شاخصهاى سنجش فضاى كسبوكار}

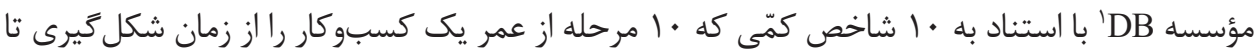
انحلال آن دربر مى گيرد، درباره ميزان مناسب مأبودن محيط اقتصادى كشور براى انجام فعاليت اقتصادى قضاوت

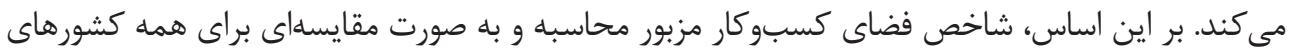

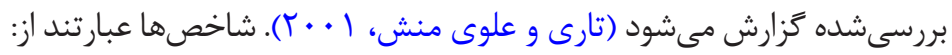
ا. شروع كسبوكار: اين شاخص فرايند ثبت شركت را از نظر تعداد مراحل، مدتزمان موردنياز و هزينه

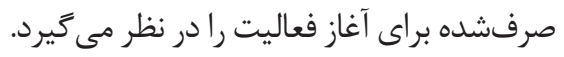

آسانسازى شرايط شروع كسبوكار، از جمله اولين مراحلى است كه براى بهبود فضاى كسبو كار مورد

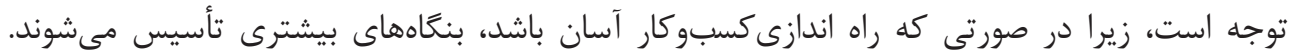

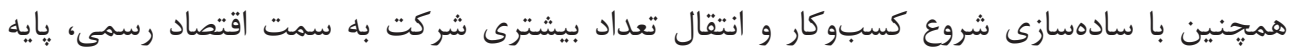

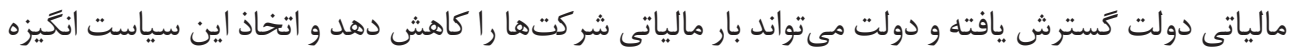
بيشترى براى توليد ايجاد مى كند.

ك. اخذ مجوزها: شامل تمامى فرايند لازم براى اخذ مجوزهاى موردنياز تا تأسيس و راهاندازى يك كار كاه است

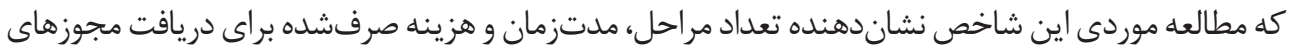

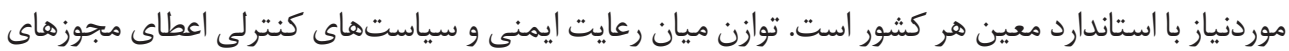

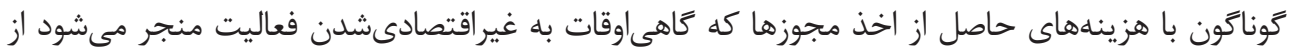

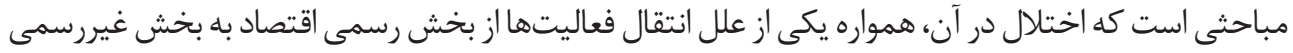

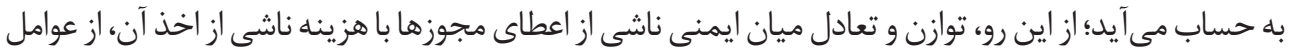




\section{ييشروى آسانسازى فضاى كسبوكار است.}

س. شاخص استخدام و اخراج نيروى كار: ميزان دشوارى استخدام، انعطاف يذيرى ساعت كار، دشوارى اخراج،

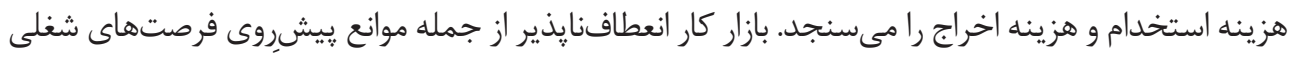

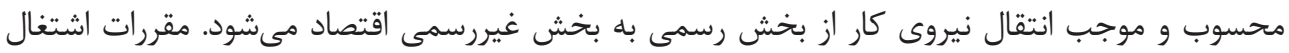

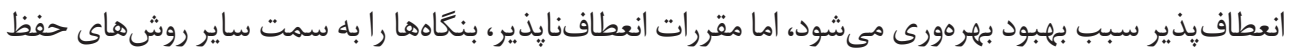

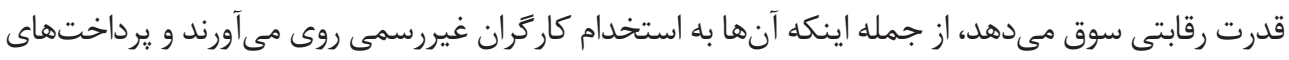

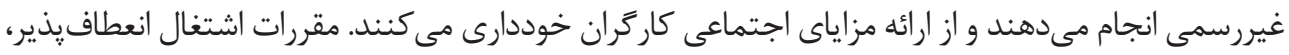

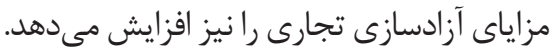

هز ثبت مالكيت: فرايند لازم به منظور ثبت دارايى در دفتر اسناد رسمى است. تعداد مراحل، مدتزمان و

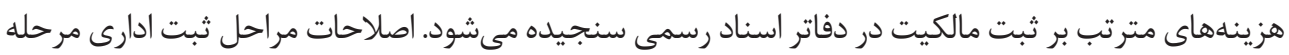

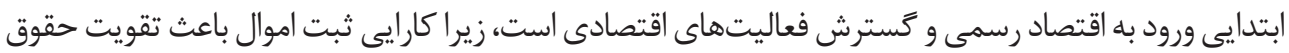

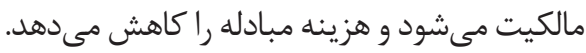

ه. اخذ اعتبار: اين شاخص به ميزان توانمندى، امكان سنجش كسترده، دقت اطلاعات اعتبارى و ميزان

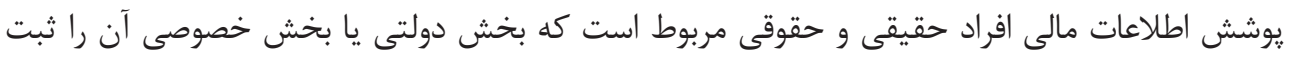

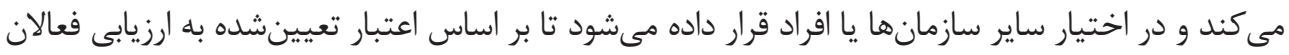

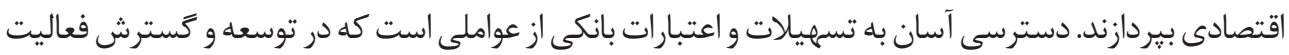

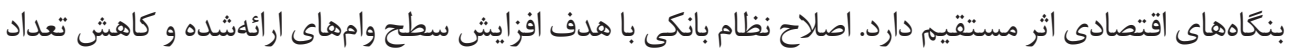

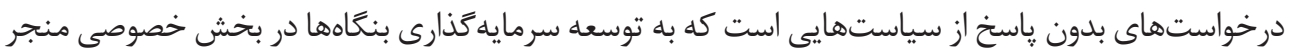
مىشود.

צ. حمايت از سرمايهَذاران: در اين شاخص اين نكته بررسى مى شود كه صاحبان سرمايه تا جه اندازه مورد

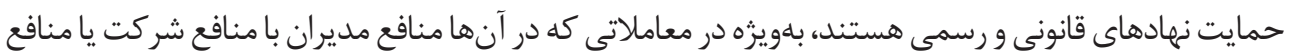

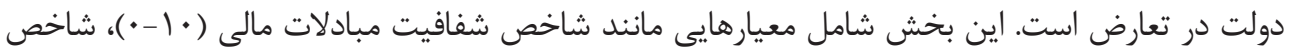

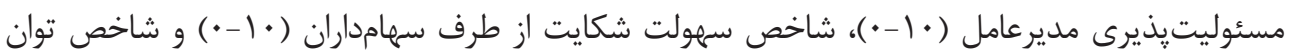

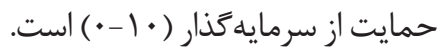

حمايت از سمامداران شركت در مقابل فعاليتهاى شخصى مديران به منظور جلوكيرى از سوءاستفاده

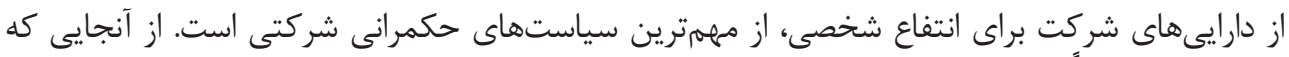

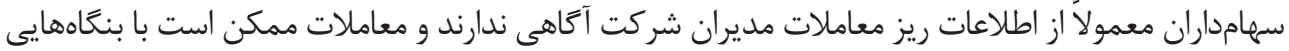

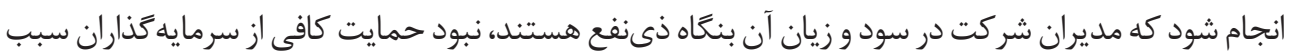

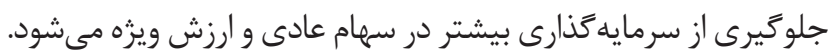
V. يرداخت ماليات: اين شاخص مآخذ تعلق ماليات، دفعات يرداخت، زمان تعيين و يرداخت و كل ماليات 


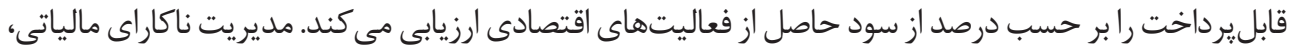

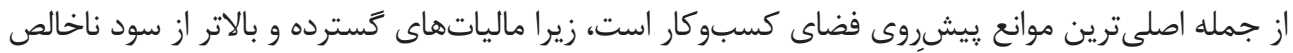

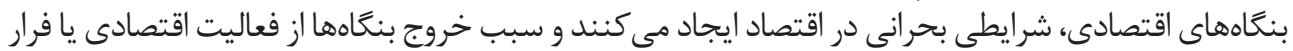
مالياتى مىشود.

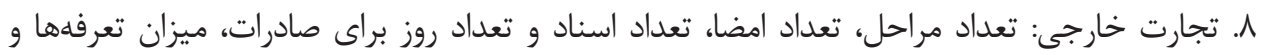

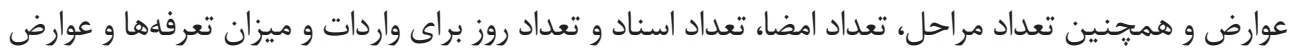

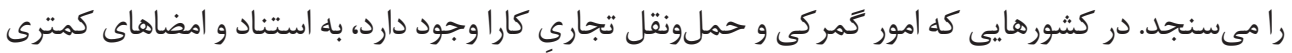

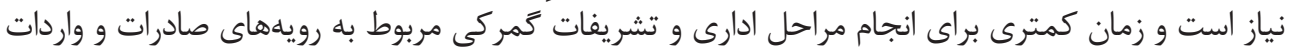

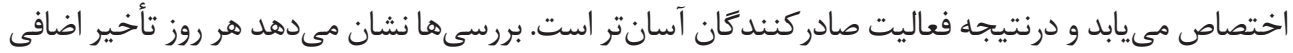

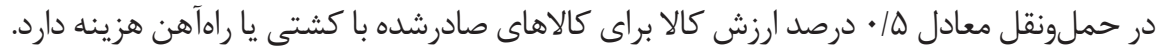

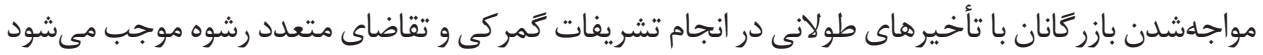

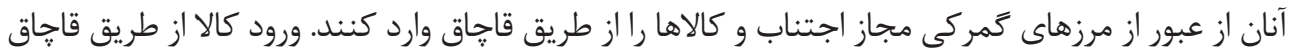

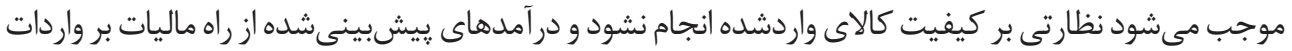
نيز حاصل نشود.

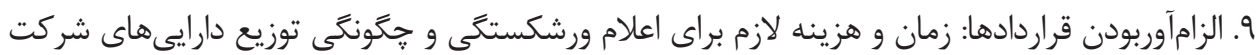

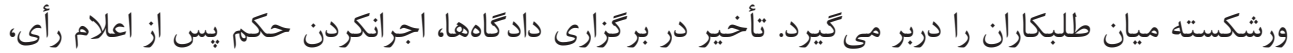

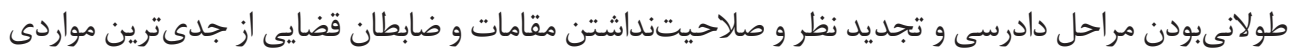

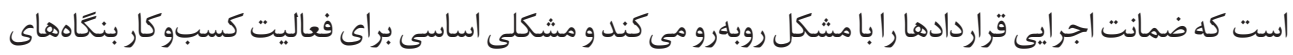
اقتصادى به وجود مى آورد.

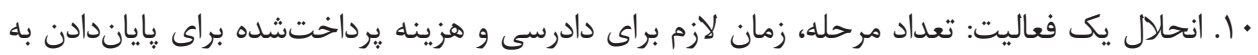

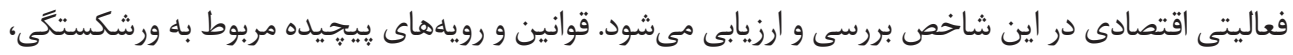

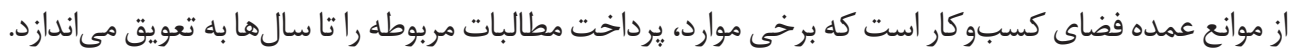

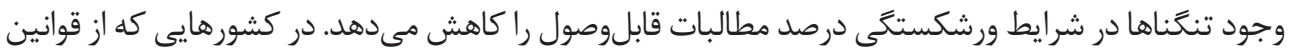

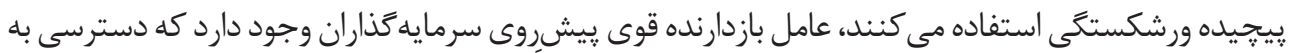

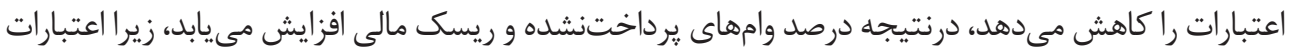

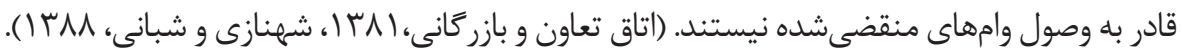

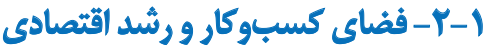

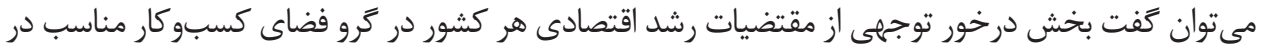

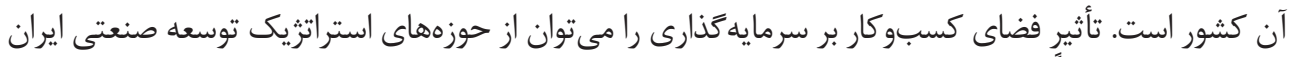

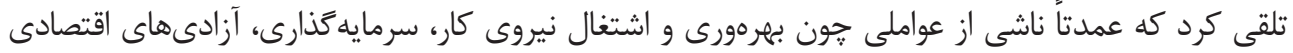




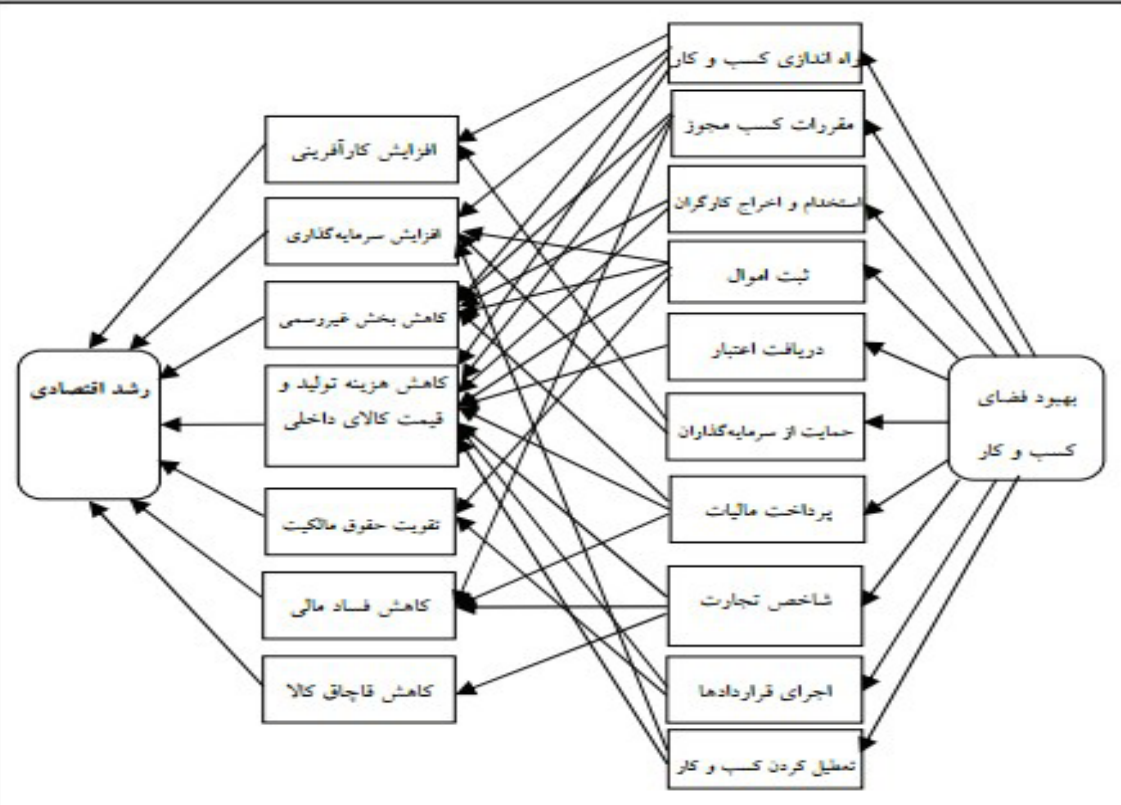

(1)

تصوير ا. مسيرهاي اثركذارى فضاى كسبوكار بر رشد اقتصادى

توليدكنندگان و ظرفيتهاى توليدى است. از طرف ديخر، توسعه اقتصادى بر پايه رقابتيذيرى كشورها استوار

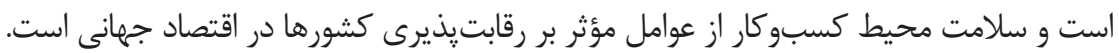

بهبود شرايط و شاخصهاى فضاى كسبو كار از جمله توسعه نظام بانكى و كاهش زمان لازم براى اخذ مجوز،

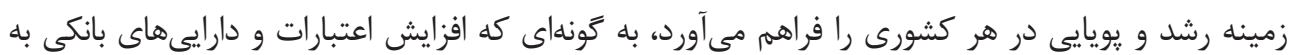

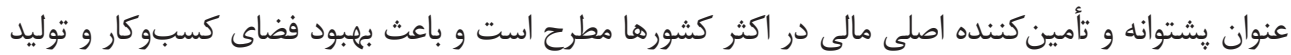

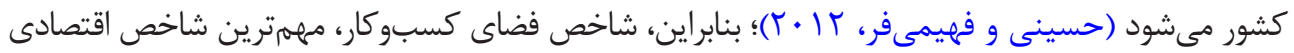
در رشد و شكل گيرى بخش خصوصى و ور افزايش رشد اقتصادى جامعه است.

در ادبيات مربوط به رشد و توسعه اقتصادى، همواره اين برسش مطرح بوده است كه جرا برخى از كشورها

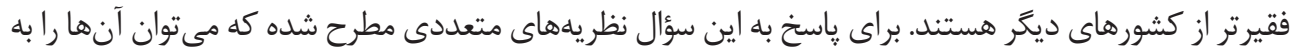

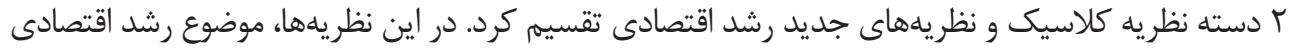

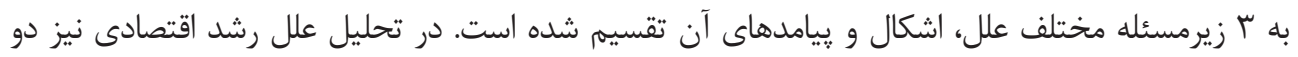

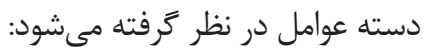

ا. علل مستقيهم (يا آشكار) مانند انباشت سرمايه فيزيكى و انسانى، تغيير فنى درونزا و غيره؛ 
r. علل غايى (يا اصلى) مانند شانس، عوامل جغرافيايى، سرمايه اجتماعى و فرهنَ و نهادها بهويزه نهادهاى اقتصادى، از جمله حقوق مالكيت و نهاد بازار و غيره (رنانى، دلالى اصفهانى و حسينى صمدى، 9 و . . ؟). از آنجايى كه الكَى سولو نقطه آغاز تمامى تحليلهاى رشد است، درك اين الكو براى درك نظريههاى رشد،

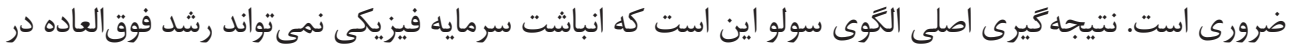

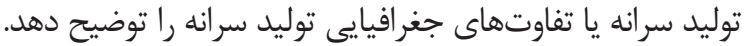

در ارتباط با بحث رشد اقتصادى در ايران، نگاهى به نتايج مطالعات انجامشده درباره رشد اقتصادى ايران نشان

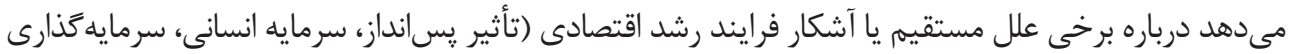

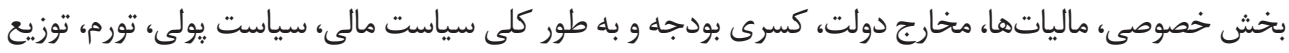

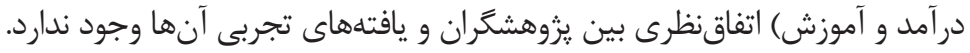

|r-1

در اين بخش به مطالعات صورتگرفته در خارج و داخل كشور اشاره مىشود.

|-1-1 - - مطالعات خارجى

كيسونكو، برونتى و ودر (999 (199) در مقالهاى با عنوان الموانع نهادى در تعريف دادههاى كسبوكار و

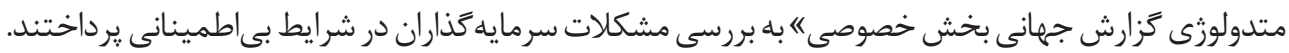

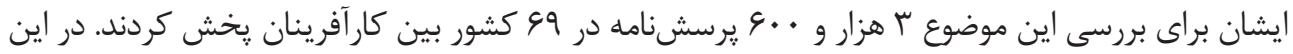

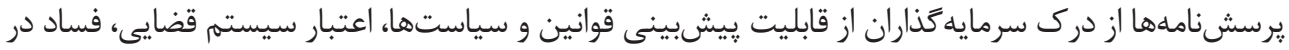

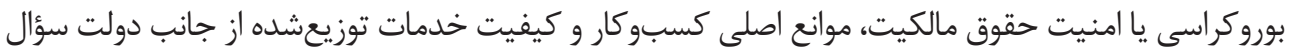
شده است.

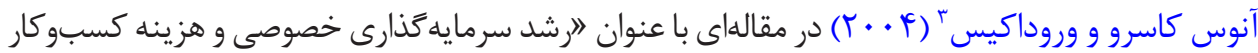

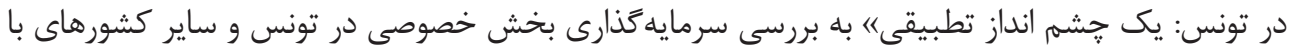

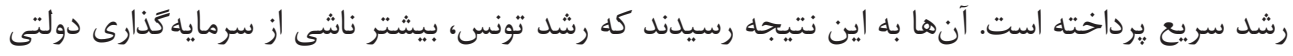

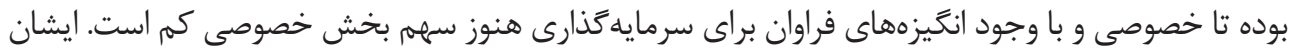

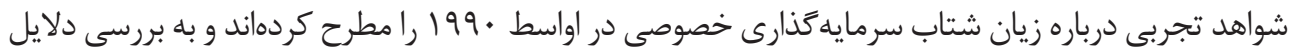

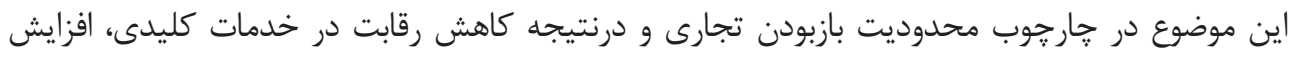

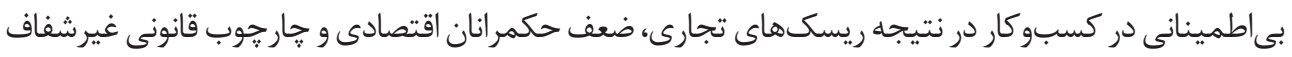
و غيرقابل ييشبينى يرداختهاند. تحليل هاى اين نويسند

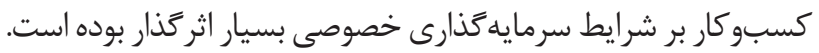

2. Kisunko, Brunetti \& Weder

3. Anos Casero \& Varoudakis 


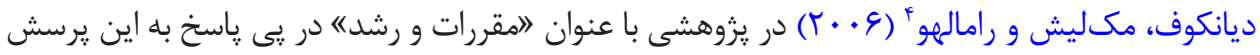

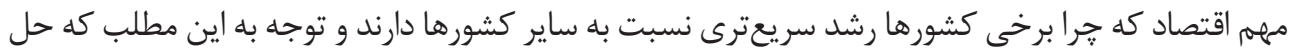

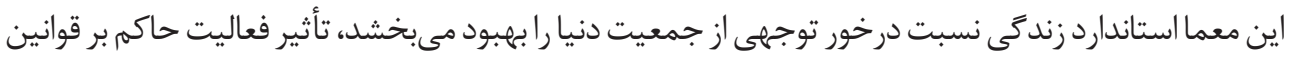

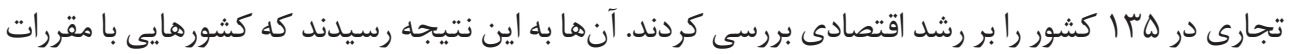

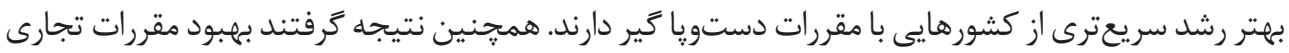

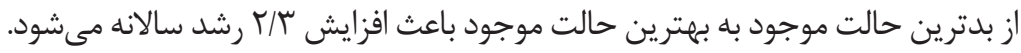

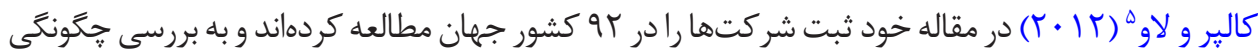

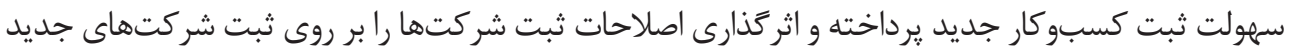

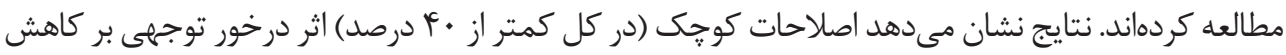

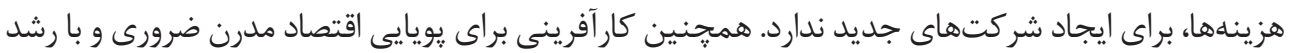
اقتصادى مرتبط است.

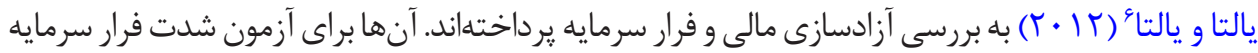

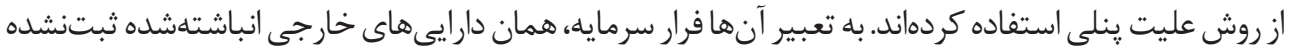

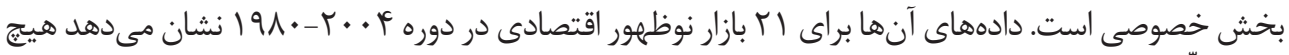

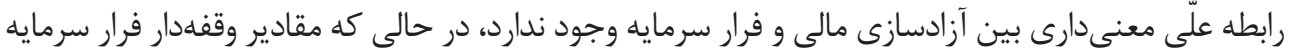

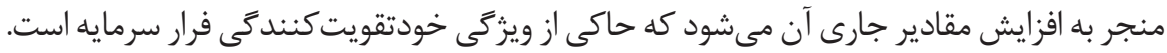

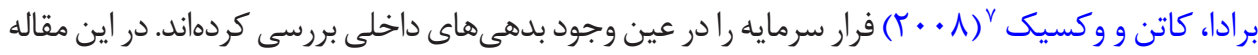

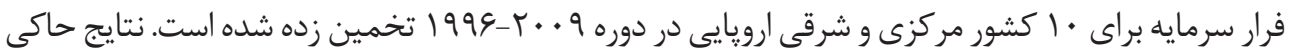

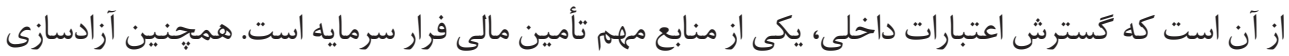

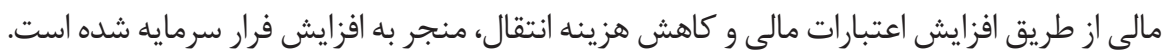

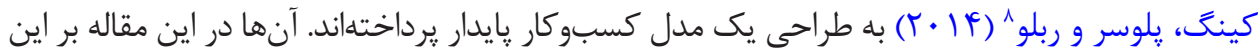

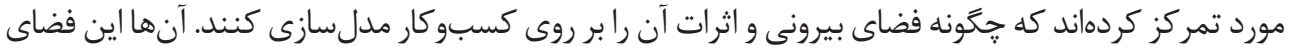

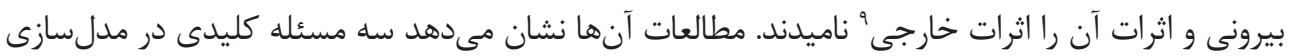

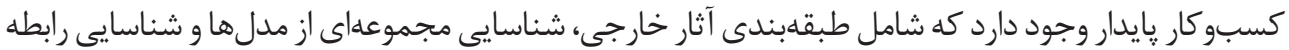

8. King, Plosser, Rebelo

9. Externalities 


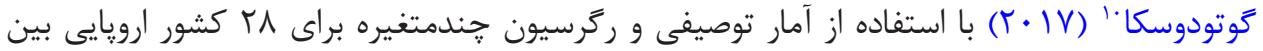

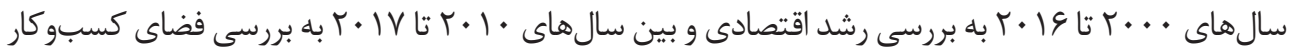

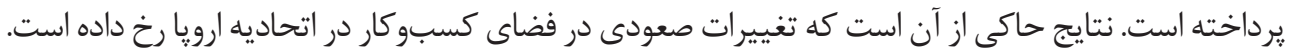

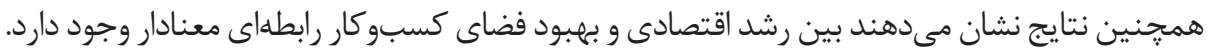

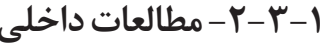

طيبى و عباسلو (9 ؟) به بررسى اعتبارات بانكى و ساير تعيين كنندههاى اقتصادى فضاى كسبوكار

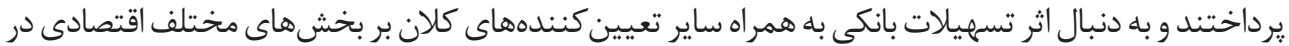

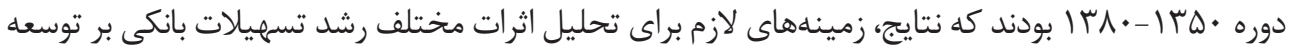

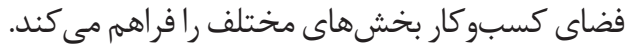

صالحآبادى ( ( • . ؟) به بررسى فرصتها و قابليتهاى بازار سرمايه و اثر آن بر فضاى كسبوكار ساير بازارها

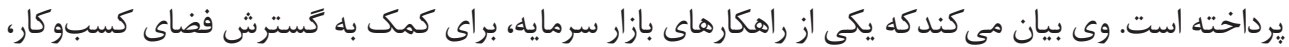

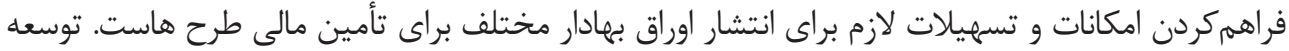

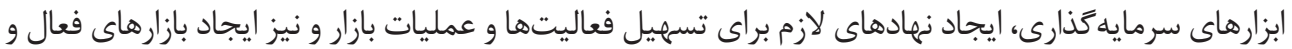

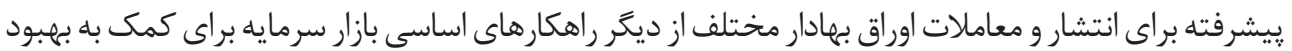

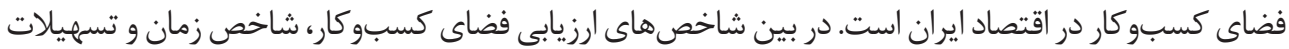

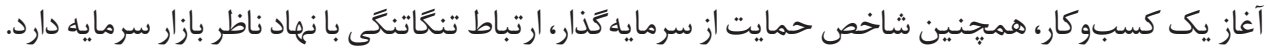
رحمانى ( • ( • ب) به ضرورت اصلاح و بهبود فضاى كسبوكار يرداخته است. وى ابتدا اهميت نظام مالى و

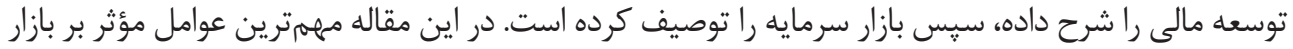

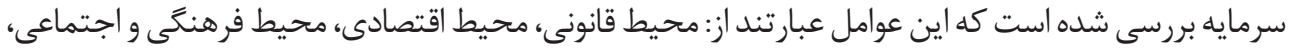

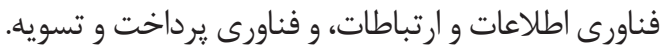

شهنازى و شبانى (1) • (1) در مقاله خود به بررسى اثر شاخصهاى فضاى كسبوكار بر رشد اقتصادى

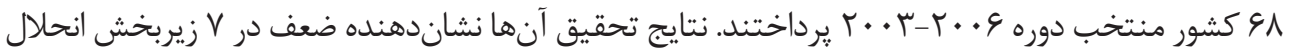

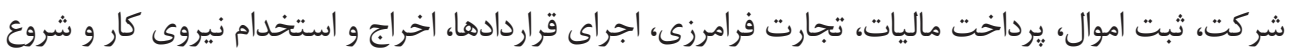

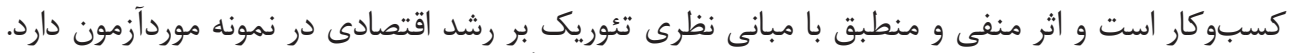

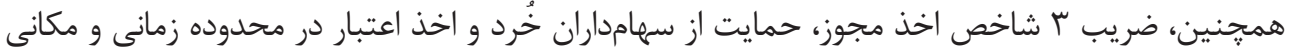

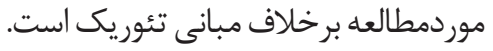

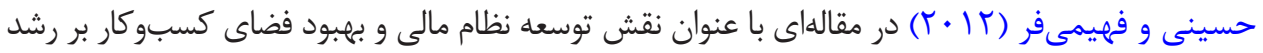

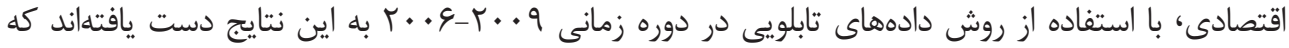


بهبود شرايط مالى و فضاى كسبو كار بر رشد اقتصادى مؤثر است، به گونهاى كه با افزايش ا 1 درصد در حجم

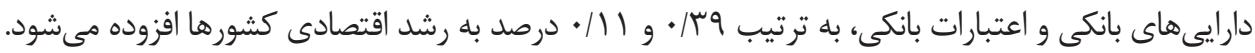

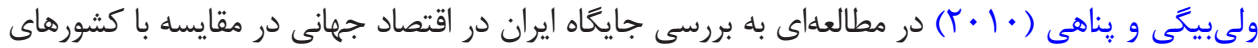

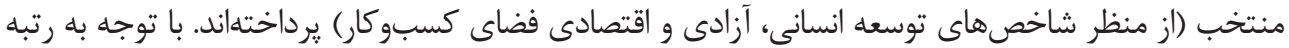

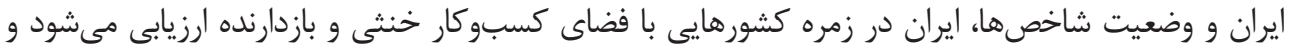

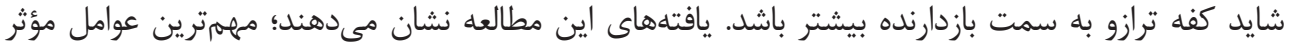

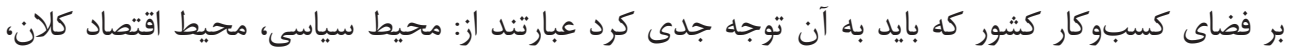

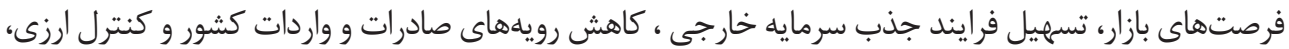

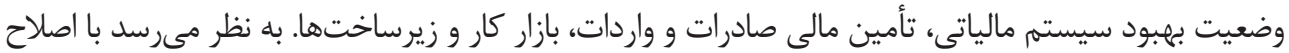

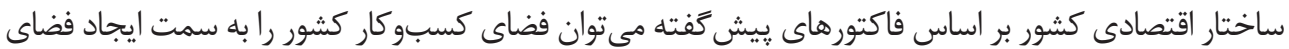
ي يشبرنده سوق داد.

حاجى حيدرى و سيد جوادين (Y| • (Y) به بررسى توسعه و تغيير مدل كسبو كار با بهكارگيرى رويكرد

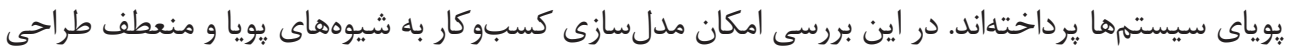

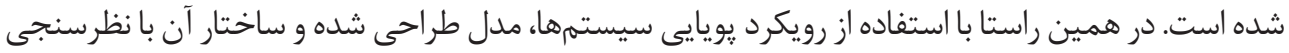

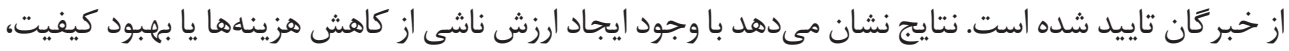

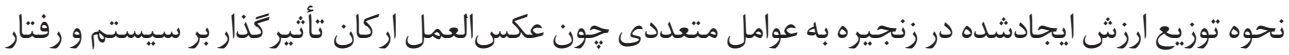
يوياى كل اركان بستخى دارد.

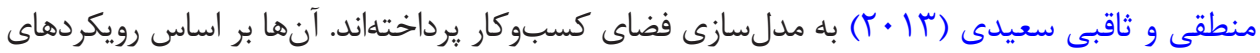

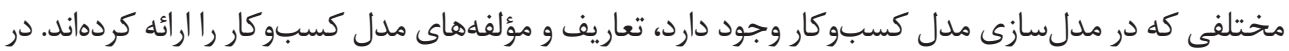

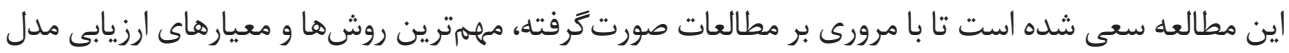

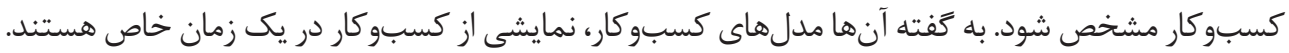

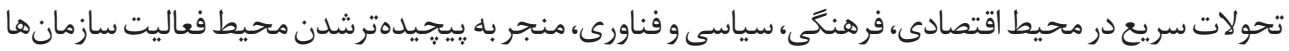

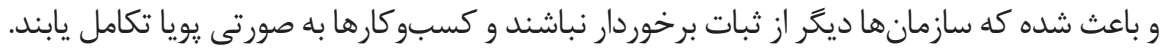

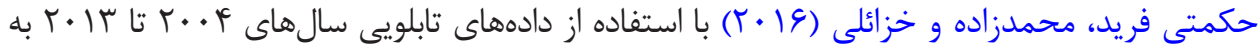

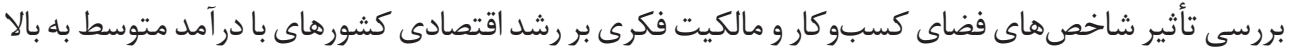

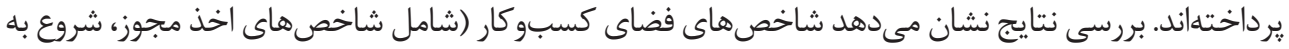

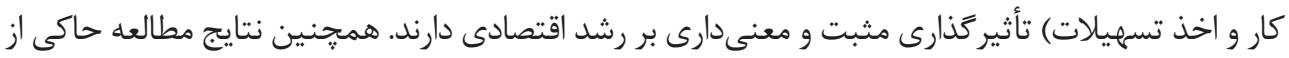

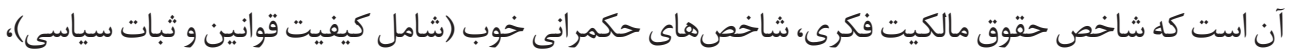

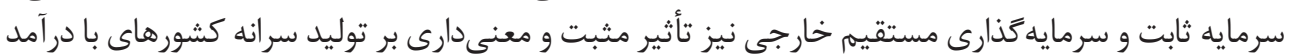
متوسط به بالا داشتهاند. 


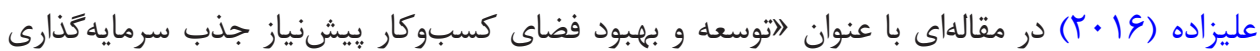

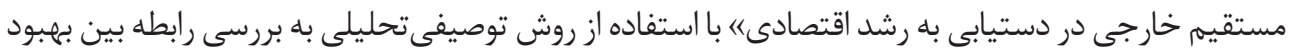

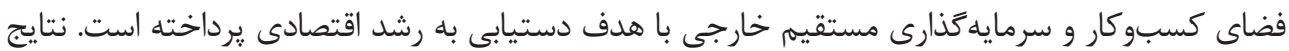

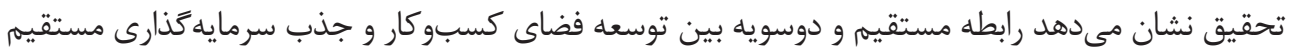

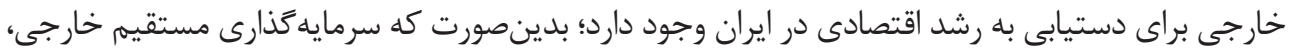

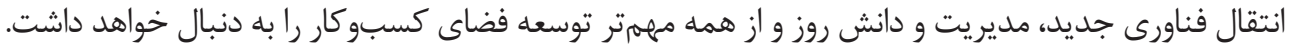

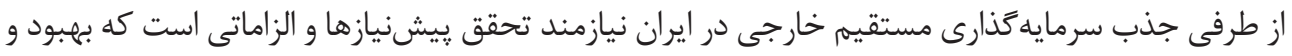

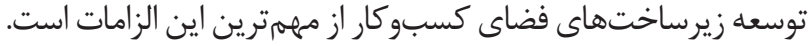

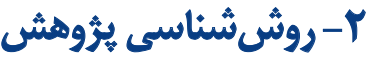

در اين مطالعه براى بررسى تأثير متغيرهاى فضاى كسبوكار بر رشد اقتصادى از روش گشتاور تعميميافته

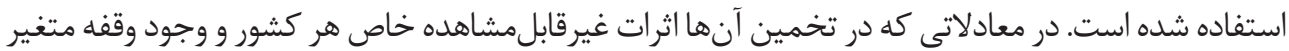

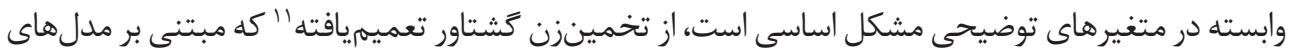

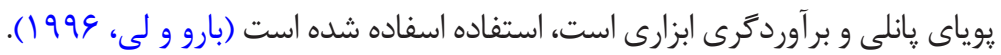
روابط يويا با حضور متغيرهاى وابسته وقفهدار در ميان متغيرهاى توضيحى مدلسازى مىشود:

$$
y_{i t}=\delta y_{i t-1}+X_{i t}^{\prime} \beta+u_{i t}
$$$$
i=1, \ldots, N
$$

$t=1, \ldots, T$

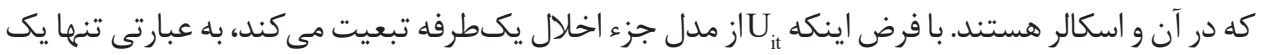
عامل موجب تفاوت مقطعهاست و آن الخوى اثرات ثابت است، دارئ داريه:

$$
U_{i t}=\mu_{i}+V_{i t}
$$

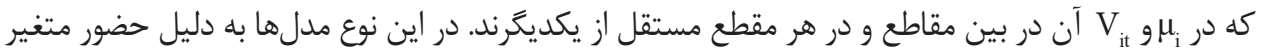

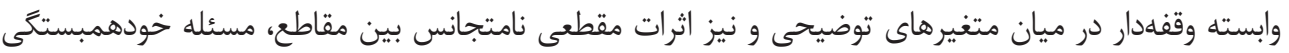

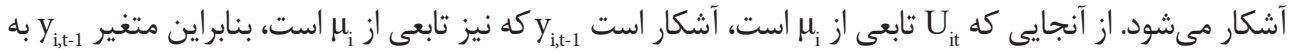

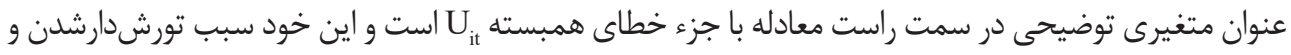

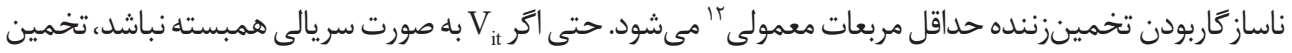

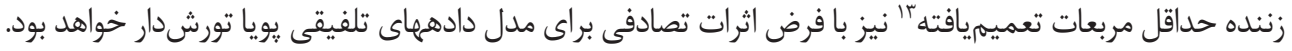


آرلانو و باند در سال ا991 19 فرايندى از روش گشتاورهاى تعميميافته ييشنهاد دادند كه كاراتر از تخمينزنندههاى

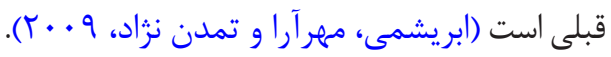

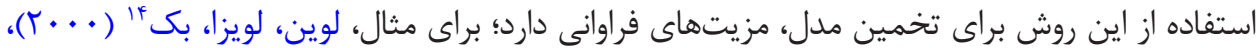

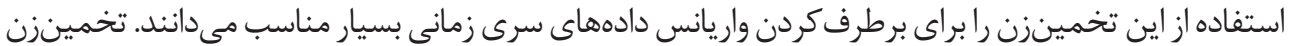

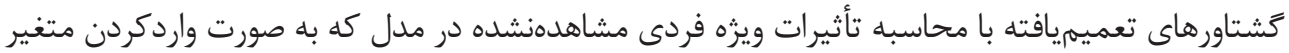

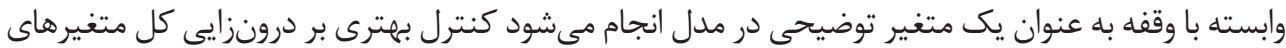

$$
\text { توضيحى مدل دارد (ياورى و همكاران، · · • (广). }
$$

يس از برآورد ضرايب، لازم است از آزمون ساركان براى بررسى معتبربودن متغيرهاى ابزارى تعريفشده

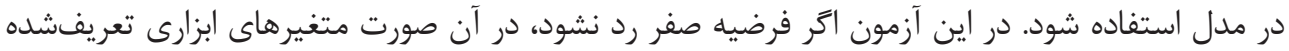

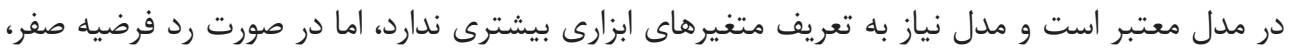

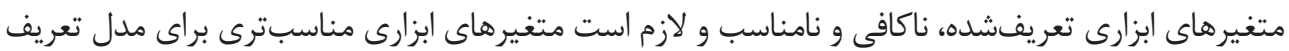

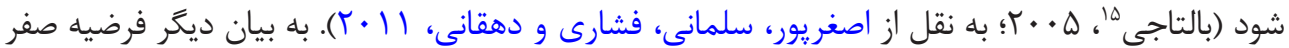

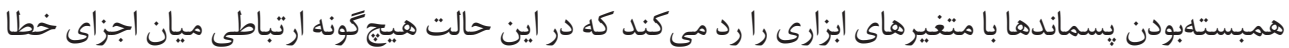

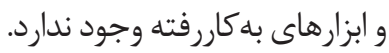

منظور از معتبربودن متغيرهاى ابزارى اين است كه متغيرهاى ابزارى تعريفشده در مدل بايد همبستگى

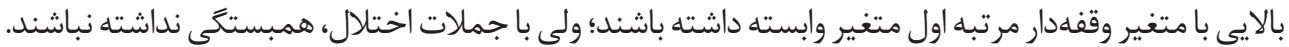

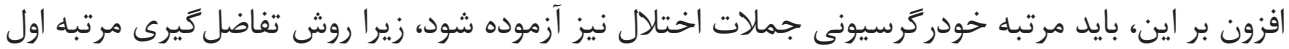

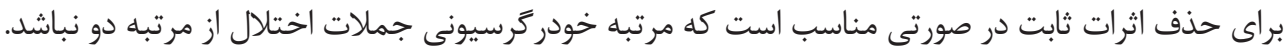

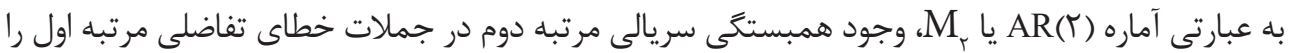

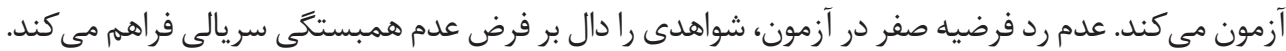

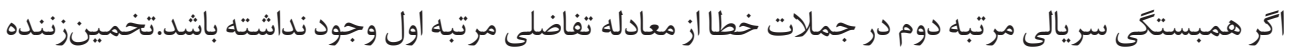
كَشتاورهاى تعميهميافته ساز كار است

\section{r- - - - - معرفي مدل تحقيق} بر اساس مبانى نظرى و مطالعات تجربى انجامشده، مدل دادهاى تابلويى يويا بر ایى بررسى اثر گذارى متغيرهاى

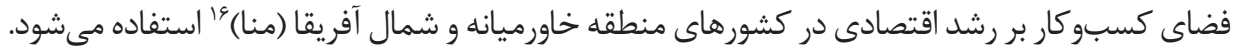

14. Levin, Loayza \& Beck

15. Baltagi

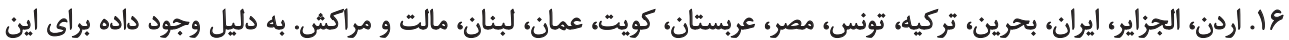

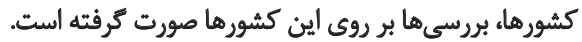




$$
G D P_{i t}=\alpha+\beta_{1} G D P_{i t-1}+\beta_{2} P E C_{i t}+\beta_{3} P R P_{i t}+\beta_{4} S I P I_{i t}+\beta_{5} C R P_{i t}+\beta_{6} C S B_{i t}+\beta_{7} E S_{i t}+\beta_{8} P S B_{i t}+\beta_{9} T A B_{i t}+\varepsilon
$$

كه در معادله فوق، GDP: رشد اقتصادى؛ a: عرض از مبدأ، PEC: بستن قرارداد، PRP: ثبت دارايى، SIPI:

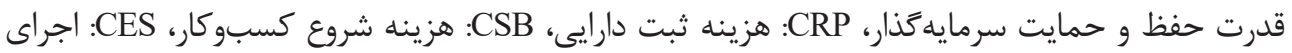

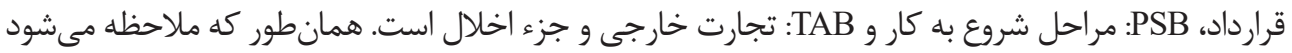

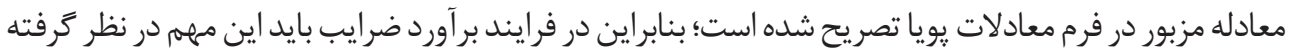

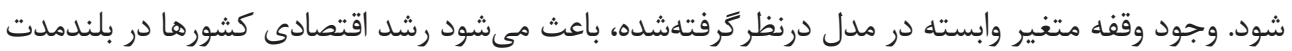

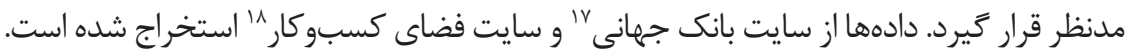

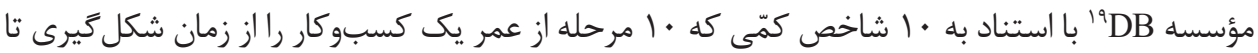

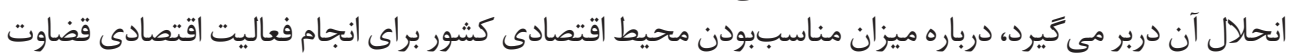

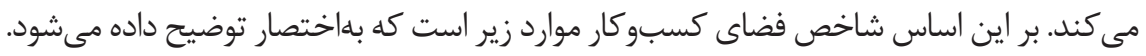
شروع كسبوكار: فرايند ثبت شركت را از نظر تعداد مراحل، مدت زمان موردنياز و هزينه صرفشده براى آغاز

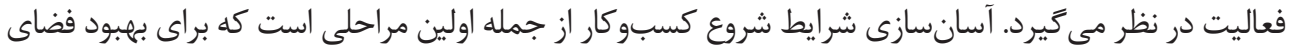

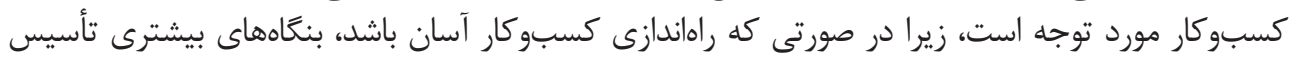
مىشوند.

قدرت حفظ و حمايت از سرمايهَذاران: در اين شاخص بررسى مىشود كه صاحبان سرمايه تا گهه اندازه مورد

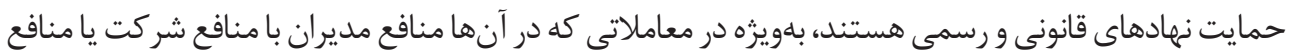

$$
\text { دولت در تعارض است. }
$$

\section{r-Y- ثبت دارايى شركت: تعداد مراحل، مدثزمان و هزيثه}

تجارت خارجى: تعداد مراحل، تعداد امضا، تعداد اسناد و تعداد روز براى صادرات، ميزان تعرفهها و عوارض و

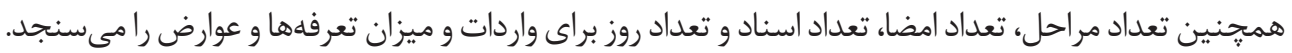
الزامآوربودن قراردادها: زمان و هزينه لازم براى اعلام ورشكستخى و جُكَنَى توزيع دارايىهاى شركت

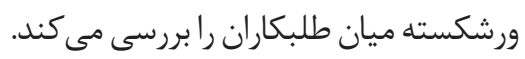

ثبت مالكيت: فرايند لازم براى ثبت دارايى در دفتر اسناد رسمى است. تعداد مراحل، مدت زمان و هزينههاى

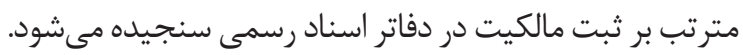

17. WDI

18. World Bank Doing Business, the International Bank for Reconstruction and Development, www.doingbusiness. org/economyrankings

19. Doing Business 
جدول ا. نتايج برآورد مدل به روش كُشتاور تعميميافته متغير وابسته رشد اقتصادى

\begin{tabular}{|c|c|c|c|}
\hline ارزث الحتمال & أماره Z & ضريب & نام هيثغير ها \\
\hline.$/ R$ & $-1 / \Delta T^{\mu}$ & $-T / E A$ & $C$ \\
\hline .1 .18 & - M/PE &.- .18 & PEC \\
\hline .1 .40 & $-r / M$ &.$- / / r$ & PRP \\
\hline.$/ r$ & $-1 / \Delta f$ &.$- / M r$ & CES \\
\hline .100 & $-1 / 2$ & $-.1 \cdot P V$ & $\mathrm{CSB}$ \\
\hline .1. & $P / W$ & $.1+4 \lambda$ & ESSI \\
\hline $.1 .+1$ & $-r / r$. & -.110 & CLRI \\
\hline $.1 \ldots$ & $\varphi / . \Delta$ & . & TAB \\
\hline$\star N$ & $V / T^{\mu}$ & +189 & $\operatorname{GDP}(-1)$ \\
\hline \multicolumn{2}{|c|}{$.10+\infty$} & $N \Delta V / T Y$ & آلماره wald \\
\hline \multicolumn{2}{|c|}{$.18 A$} & r/af & ألماره ساركان \\
\hline \multicolumn{2}{|c|}{. IAr } &.$- / 94$ & ARY آماره \\
\hline
\end{tabular}

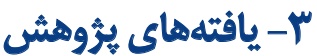

در اين مطالعه به بررسى تأثير مؤلفههاى فضاى كسبوكار بر رشد اقتصادى كشورهاى منطقه خاورميانه و

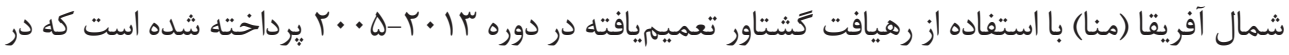

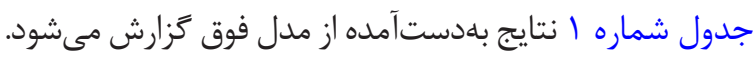
بر اساس نتايج بلدستآمده، مىتوان بيان كرد وقفه متغير وابسته تأثير مثبت و معنى دار دارد و بيانگر اين

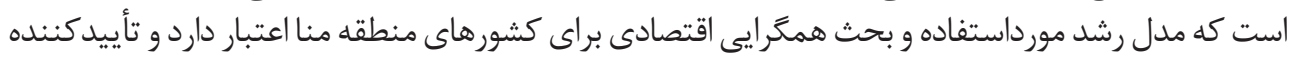

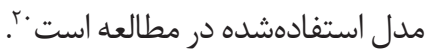

بر اساس جدول شماره ا، نتايج آماره آزمون ساركان بر ردنشدن فرضيه صفر و معتبربودن متغيرهاى ابزارى

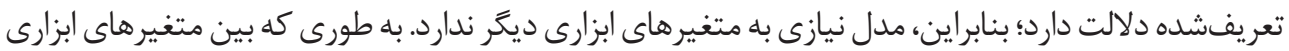

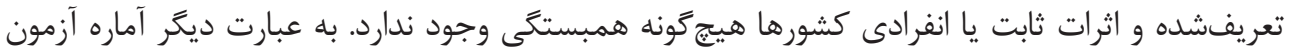

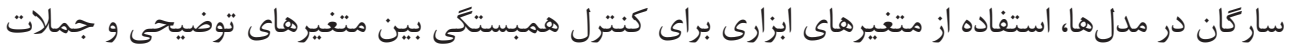


اختلال را تأييد مى كند. در ادامه به منظور آزمون فرضيه خودهمبستكى جملات اختلال، از آماره آزمون آرلانو

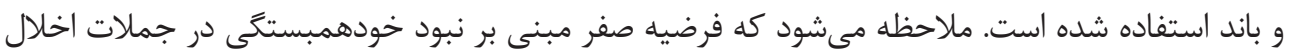

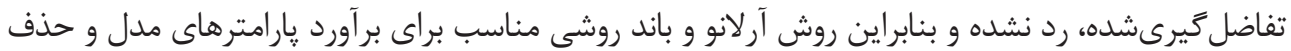

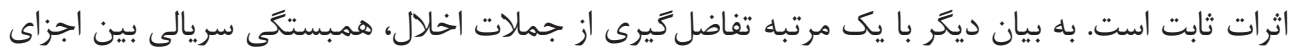

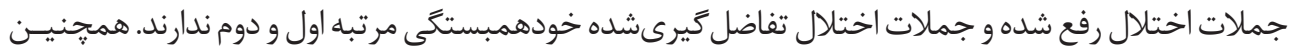

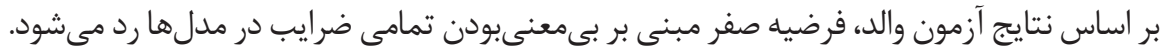

با توجه به اينكه برخى از متغيرها تأثير معنى مدارى بر مدل نداشتهاند آ، از مدل حذف شده تا مدل بهتر

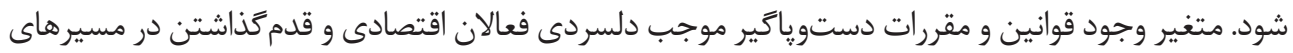

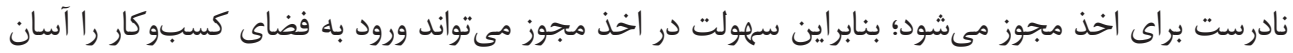

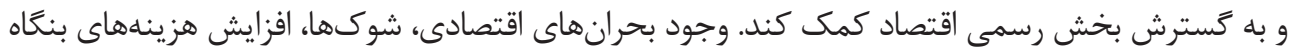

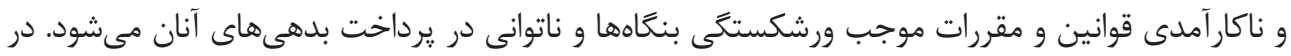

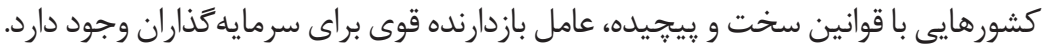

متغير تجارت، اثر مثبت، تأثير مثبت و معنى دارى بر رشد اقتصادى دارد و با افزايش ميزان تجارت در

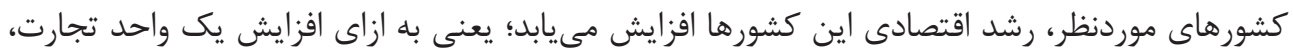

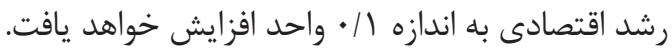

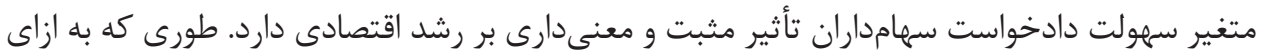

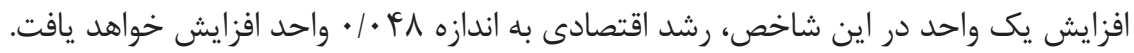

هم:ٌنين متغير هايى مانند مراحل شروع كسبو كار، اجراى قرارداد، حمايت از سرمايهَذار و ثبت اموال

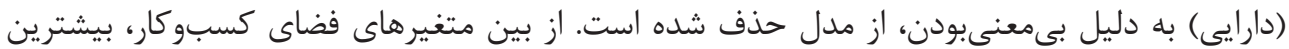

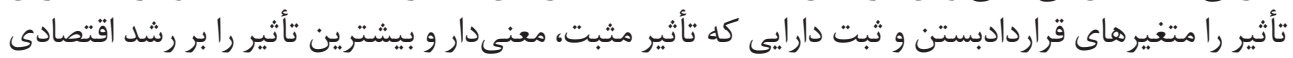

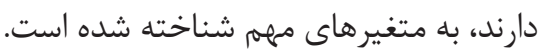

\section{ع- بحث و نتيجه كَيرى}

با توجه به اينكه بهبود محيط كسبوكار موجبات رشد اقتصادى را فراهم مى آورد، هدف اين :زثوهش

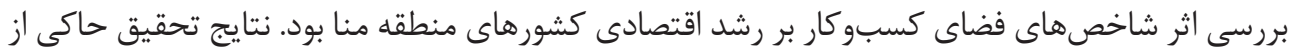

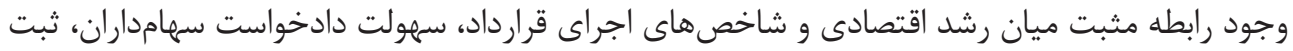

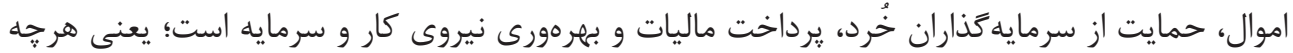

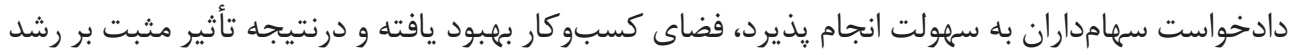

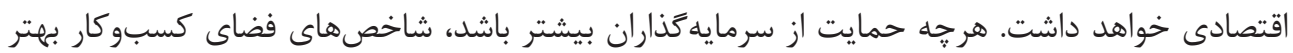

آ. با استفاده از آزمون خطاى تصريح مدل و آزمون معنى دارى كل ركر سيونه برخى از مثغيرها از مدل حذف شدهاند. 
شده و درنتيجه رشد اقتصادى افزايش خواهد يافت. هرجهه بهرهورى نيروى كار و سرمايه بيشتر باشد، رشد

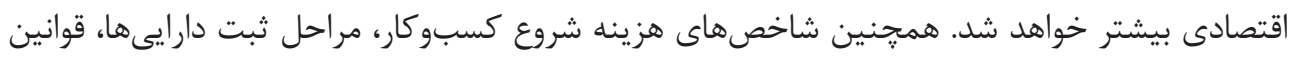

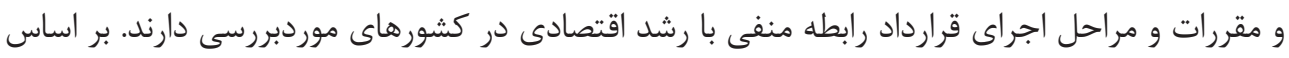

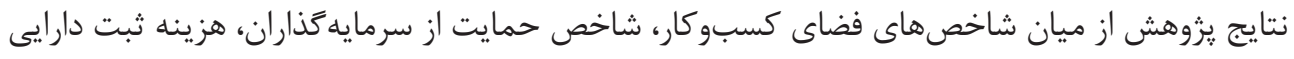

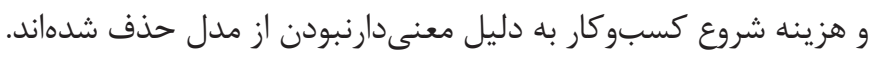

با توجه به اينكه بهبود فضاى كسبو كار نقشى اساسى در افزايش رشد اقتصادى كشورها ايفا مى كند،

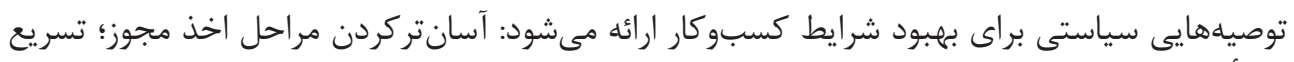

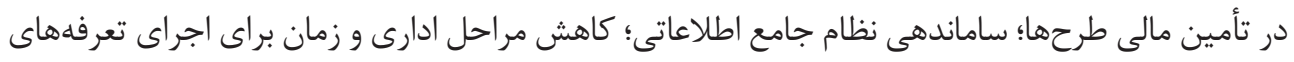
كمر كى؛ سادهسازى قوانين و مقررات.

مالاحظات اخلاقي

$$
\text { حامي مالى }
$$

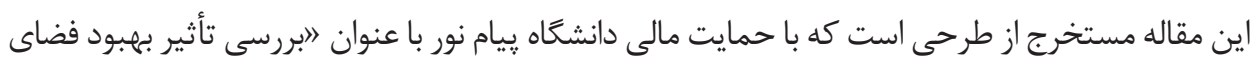

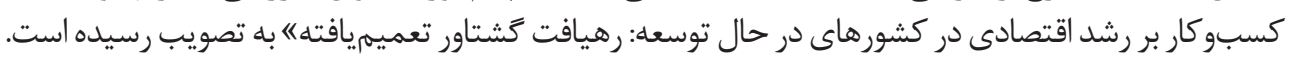

\section{تعارض منافع}

بنا به اظهار نويسندَان، در اين مقاله هيجَّونه تعارض منافعى وجود ندارد. 


\section{References}

Abrishami, H., Mehrara, M., \& Tamadonnejad, A. (2009). [Study of the relationship between foreign trade and economic growth in developing countries: Generalized torque approach (Persian)]. Journal of Science and Development, 16(26), 45-62.

Alizadeh, N. (2016). [Developing and improving the business environment is a prerequisite for attracting foreign direct investment to achieve economic growth (Persian)]. Economic Journal, 16(7-8), 33-81.

Anos Casero, P., \& Varoudakis, A. (2004). Growth, private investment, and the cost of doing business in Tunisia: A comparative perspective. Washengton: The World Bank.

Asgharpur, H., Salmani, B., Feshari, M., \& Dehghani, A. (2011). [The effect of administrative corruption on the gross national saving in MENA Countries (dynamic panel data approach) (Persian)]. Journal of Eye Movement Research, 1(3), 99-121.

Bakhtiari, S., \& Shayesteh, A. (2012). [An assessment of business environment improvement on economic growth in selected countries with emphasis on Iran (Persian)]. Eghtesad-e Mali, 6(19), 175-204.

Barro, R. J., \& Lee, J. W. (1996). International measures of schooling years and schooling quality. The American Economic Review, 86(2), 218-23.

Boroomand, Sh. (2008). [Economic security in Iran and several selected countries (Comparative study) (Persian)]. Tehran: Islamic Consultative Research Center.

Brada, J. C., Kutan, A. M., \& Vukšić, G. (2008). Estimates and causes of capital flight from central and east european countries. Arlington, Virginia: Emerging Markets Group.

Djankov, S., McLiesh, C., \& Ramalho, R. (2006). Regulation and growth. Economics Letters, 92(3), 395-401. [DOI:10.1016/j. econlet.2006.03.021]

Głodowska, A. (2017). Business environment and economic growth in the European Union Countries: What can Be explained for the convergence? Entrepreneurial Business and Economics Review, 5(4), 189-204.

Haji Heidari, N., \& Seyed Javadin, S. R. (2012). [Development and manipulation of business models using system dynamics approach (Persian)]. Information Management Association, 6(21), 1-18.

Hekmati Farid, S., Mohamad Zadeh, Y., \& Khazali, D. (2016). [The impact of business regulatory reforms and intellectual property rights on economic growth in upper middle income countries (Persian)]. Quarterly Journal of Economic Growth and Development Research, 6(22), 119-30.

Hosseini, M., \& Fahimifar, F. (2012). [The role of developing the financial system and improving the business environment on economic growth (Persian)]. Paper presented at The Fourth International Conference on the Development of the Financing System in Iran, Tehran, Iran, 20 February 2012.

King, R. G., Plosser, C. I., \& Rebelo, S. T. (2014). Production, growth and business cycles: I. The basic neoclassical model. Journal of Monetary Economics. Journal of Monetary Economics, 21(2), 195-232. [DOI:10.1016/0304-3932(88)90030-X]

Kisunko, G., Brunetti, A., \& Weder, B. (1999). Institutional obstacles to doing business: Region-by-region results from a worldwide survey of the private sector. Washington: The World Bank.

Klapper, L., \& Inessa, L. (2012). the impact of business environment reforms on new firm registration. Washington: The World Bank. [DOI:10.1596/1813-9450-5493]

Levin, R., Loayza, N., \& Beck, T. (2000). Financial intermediation and growth: Causality and causes. Journal of Monetary Economics 46 (2000) 31-77. 
Maderi, A., \& Ghodjani, A. (2008). [Measuring and improving the business environment (Persian)]. Tehran: Academic Center for Education, Culture and Research.

Manteghi, M., \& Saghebi Saeedi, F. (2013). [Business models, foundations, evaluation, innovation (Persian)]. Roshd-e-Fanavari, 9(35), 39-51.

Rahmani, A. (2010). [Market, the need for improving and improving the business environment (Persian)]. Journal of Monetary \& Banking Research, 1(1), 145-75.

Renani, M., Dallali Isfahani, R., \& Hossein Samadi, A. (2009). [Property rights and economic growth: An endogenous growth mod (Persian)]. Journal of Economic Research, 43(4), 175-206.

Salari, A. (2011). [The impact of the tax system on the business space (Persian)]. Economic Journal, 11(9), 111-30.

Saleh Abadi, A. (2009). [The role of capital market in improving the business environment of Iran (Persian)]. Journal of Monetary \& Banking Research, 1(1), 101-21.

Shahnazi, R., \& Dehghan Shabani, Z. (2011). [Investigating the impact of business space on economic growth in selected countries (Persian)]. Economics Research. 11(42), 161-85.

Tabnak. (2014). [Report of World Bank business (Persian)]. Retrieved from: https://www.tabnak.ir/fa/news0

Tari, F., \& Alavimanesh, S. M. (2001). [Improving business space in the fifth development plan (Persian)]. Majlis \& Rahbord, 18(67), 47-89.

Teibi, K., \& Abaslou, Y. (2009). [Bank credits and other determinants of the economy of business space in Iran (Persian)]. Monetary \& Banking Research, 1(22), 57-78.

Vali Beigi, H., \& Panahi, R. (2010). [The position of Iran in the global economy and in comparison with the selected countries (from the perspective of human development indicators, economic freedom and business space) (Persian)]. Institute for Trade Studies and Research, 8(43), 27-42.

Yalta, A. Y., \& Yalta, A. T. (2012). Does financial liberalization decrease capital flight? A panel causality analysis. International Review of Economics \& Finance, 22(1), 92-100. [DOI:10.1016/j.iref.2011.09.003]

Yavari, K., Reza Gholizadeh, M., Aghaei, M., \& Mostafavi, M. H. (2010). [The effect of tourism on economic growth: The case of OIC member countries (Persian)]. Journal of Economic Research, 45(2), 200-19. 
This Page Intentionally Left Blank 